Journal of Teacher Education for Sustainability, vol. 13, no. 1, pp. 113-128, 2011

\title{
RELATIONSHIP BETWEEN RAPID NAMING SPEED AND READING SPEED AS A MARKER OF READING DIFFICULTIES OF ESTONIAN CHILDREN FROM 6 TO 8 YEARS
}

\author{
Kadi Lukanenok \\ Tallinn University, Estonia
}

\begin{abstract}
Reading is one of the fundamental skills for successful performance in modern society. Reading acquisition is one of the most important tasks in primary level of education. The early identification of reading difficulties $(R D)$ enables educators to apply the treatment as early as possible. Rapid naming $(R N)$ is one of the reliable methods used to identify $R D$ and risk for $R D$. The relationship between $R N$ skills, especially $R N$ speed and reading decoding speed, is investigated as a good tool for predicting reading at decoding level and welldocumented in languages using non-transparent orthography. Few researches are carried out on RN skills in transparent orthographies. The current research is the first attempt to investigate RN skills of children speaking Estonian, highly transparent Finno-Ugric language. The aim of this study is to examine longitudinally $R N$ speed and decoding skills of children at the age 6, 7 and 8 years to detect the relationship between $R N$ speed in prereading age and reading age after starting formal reading instruction.
\end{abstract}

Key words: education for sustainable development, reading, naming, rapid naming speed, reading, reading difficulties

\section{Theoretical overview}

\section{Introduction}

The concept of education for sustainable development (ESD) includes the wide range lifelong learning and participatory learning experiences to ensure the benefit from quality education that can be sustained. Among the personal and professional competences stressed are educational-cognitive strategies, mastery of planning, analysis and reflection, methods of problem solving, informational processing and communicative competences. These abilities enable to search, analyse, select and process the necessary information independently, communicate and proceed professional activity as sustainability guaranteed competences (Makarevičs, 2008; Scanavis \& Sakellari, 2009). 
Contemporary Estonian Republic regulations in educational field (Estonian Teachers' 5th Professional Standard, 2005; National Law of Basic School and Gymnasium, 2010) point out the importance of inclusive education and especially highly valued domains in the teachers' professionalism: developing learning environment, motivation, guiding learning and analysing and assessing learners' development and study process. Consequently, the teachers' professional competence plays a major role in the sustainability of society (Kukk $\&$ Talts, 2007).

According to the aforementioned research, there is an increased demand in education based on reading ability and reading skills. Reading, reading acquisition and the educators' competences to identify and manage possible reading difficulties and diversities in the educational process had become one of the crucial issues in education.

Reading is one of the fundamental skills for successful performance in modern society. Reading skills are the basis for gaining an occupation and acquiring further professional development. Reading ability ensures an individual's performance in society and guarantees personal sustainable development. Great attention is needed to support achievement of reading skills in the primary school.

Specific reading difficulties (SRD) and dyslexia are caused by biological, psychological and cognitive factors despite of support for students in the social and pedagogical environments. Much research has been done in the areas of cognitive and linguistic processes, and some verbal skills in the pre-reading period may be related to later performance in readingVIIDE. The level of pre-reading and reading skills, i.e. naming, rapid naming, phonological processing and awareness have especially great value in the context of reading prediction both by scientific and practical perspectives (Denckla \& Rudel, 1974; Pastarus, 1999; Wolf, 1999; Wolf \& Bowers, 1999; Goswami, 2000; Holopainen, Ahonen, \& Lyytinen, 2001; Van der Leij, Lyytinen, \& Zwarts, 2001; Nation, 2005; Shaywitz, 2003; Wolf \& Denckla, 2005).

The reading difficulties discovered at an early age are likely to be mitigated or overcome by using effective intervention strategies and methods. The efficiency of intervention is directly related to detection of the difficulties as soon as possible (Boscardin, Muthén, David, \& Baker, 2008; Nation, 2005).

Research on Estonian students' reading skills indicate that students with low achievements in reading skills in Form 1 have low general educational success in Form 3 as well (Pandis, 2002).

\section{Naming and rapid naming}

The naming process involves the sub-processes of storing, finding and retrieving word sounds in memory and rapid and adequate speech production. It is considered as attribution and utilization of the linguistic equivalent (symbol) to the objects, characteristics and actions (Luria, 1962).

Naming ability is based on a number of cognitive processes: visual perception, auditory perception, linguistic processes and memory (storing, preservation and retrieval). Integration of the auditory and visual memory, memory processes, motor and executive 
processes with language processes, particularly word identification and automaticity, are of crucial importance (Wolf, 1991, 1999; Wolfe \& Nevills, 2004; Heikkilä, 2005; Stackhouse, 2006; Arnell, Joanisse, Klein, Busseri, \& Tannock, 2009).

Rapid naming is considered to be the ability to name the presented stimulus and move ahead to the next stimulus as fast as possible. Research has shown that the speed of rapid naming has more diagnostic value than correctness of rapid naming in evaluation of risk for SRD especially in the languages of transparent orthography (one to one phoneme-grapheme correspondence), for instance, Finnish, Greek, Spanish (Wolf, 1986; Wolf \& Bowers, 1999; Aro, 2004; Holopainen et al., 2001; Salmi, 2008).

Modern studies of rapid naming started in the 1970's when Denckla and Rudel (1974) noticed that children with specific reading disabilities differed from children with age related reading in rapid naming speed.

In recent times, numerous tests of rapid naming have been constructed. Rapid naming tests consist of sequences of various stimuli which the examinee has to name as fast and correctly as possible. The task of the examinee is to identify the stimuli, find and produce the correct name and move to the next stimuli as fast as possible. The most relevant criteria to measure RN are considered naming speed and accuracy (Wolf \& Denckla, 2005; Wolfe \& Nevills, 2004).

Researchers have asserted that $\mathrm{RN}$ and reading performances are connected, and $\mathrm{RN}$ could predict reading performance. $\mathrm{RN}$ speed has been identified as an especially strong predictor for SRD in regular orthographies (Wolf, 1986; Wolf \& Bowers, 1999; Holopainen et al., 2001; Aro, 2004; Salmi, 2008).

\section{Correlation between rapid naming and reading}

Naming is related to reading by neurogenetic and cognitive factors. A number of researches (Grigorenko, 2004; Samuelsson, Byrne, Quain, Wadsworth, Corley, DeFries, Willcutt, \& Olson, 2005) have evaluated the relation between $\mathrm{RN}$ and heredity and have found it to be medium or strong $(\mathrm{r} \sim .60)$

The relevant functional regions of the brain that underpin naming and $\mathrm{RN}$ processes allow reading process to be performed in the same way. The development of naming skills is considered as a function of age and cognitive ability (Luria, 1962; Laine, 1995; Karlep, 2003; Messer \& Dockrell, 2006). The researches (Denckla \& Rudel, 1976a; Wolf, 1991, 1999; Goswami, 2000) stress the common cognitive, perceptual and linguistic subprocesses characteristics for both naming and reading processes. Naming skills are considered important in reading acquisition especially in alphabetic-phonetic orthographies. Naming speed is directly connected to word identification, word reading effectiveness and comprehension by temporal processes common to linguistic and motor functions.

Incorrectness and slow naming speed refer to SRD and are characteristics for both SRD and general learning difficulties (Denckla \& Cutting, 1999; Wolf, 1999; Waber, Wolff, Forbes, \& Weiler, 2000; Misra, Katzir, Wolf, \& Poldrack, 2004; Messer \& Dockrell, 2006; Heikkilä, Närhi, Aro, \& Ahonen, 2008). 
Research suggests a connection between $\mathrm{RN}$ and reading/decoding. The level of $\mathrm{RN}$ is considered one of the strongest indicators of reading performance. RN speed is related to later reading speed, text reading fluency and reading comprehension.

RN and reading have several common cognitive processes (Geschwind, 1965; Denckla \& Rudel, 1976a, 1976b; Wolf, 1991, 1999). At the input level, RN assumes direction of attention to both the presented stimuli and modality perception. At the processing level, RN requires evaluation, classification and activation in working memory and retrieving and integrating information with lexical (phonological and semantic) information stored in memory. At the output level, the RN process is related to motor activity which leads to variations of articulation and pauses.

So far, the precise mechanism of the aforementioned connection is not fully clear, but many different associations have been found. Several researchers have indicated that people with RN difficulties have more reading difficulties than those whose word RN does not cause any problems or errors. Poor readers differ from regular readers by the RN speed and/or amount of mistakes in naming tasks. Consequently, the level of RN predicts RD both in regular and irregular orthographies (Denckla \& Rudel, 1974; Wolf, 1986; Korhonen, 1995; Salmi, 2008). RN speed has more diagnostic value than correctness in regular orthographies (Wolf, 1986; Wolf \& Bowers, 1999; Holopainen et al., 2001; Aro, 2004; Misra et al., 2004).

Compton (2003), Lehtonen (1993), Savage and Fredricson (2005), Savage, Pillay and Melidona (2007) have demonstrated that RN numbers and letters (alpha-numerical stimuli) predict decoding ability and the speed and accuracy of text reading more than the rest of stimulus (non-alphanumerical). RN-pictures do not have a significant predictive value (Savage \& Fredricson, 2005; Albuquerque \& Simoes, 2010). Some researchers have shown that picture naming requires access to semantic information that is not required in letter and number naming which becomes automatic at a certain age (Savage \& Fredricson, 2005; Albuquerque \& Simoes, 2010). RN methodology enables psychological, pedagogical and special pedagogical scientific research.

\section{Rapid naming difficulties, connection to reading and reading difficulties}

Rapid naming difficulties (RND) are referred to as slow or incorrect word retrieving process and production of familiar words (Denckla \& Rudel, 1974).

RND can be taken into consideration in case that the slower responses and more mistakes than average occur in naming tests. Children with RND are considered to be at risk for failure in their reading acquisition. Naming deficits are detectable at pre-school age before the start of formal schooling and reading instruction (Wolf, 1986; Constable, 2001; Ahonen et al., 2003; Shaywitz, 2003; Heikkilä, 2005; Nation, 2005; Stackhouse, 2006; German \& Newman, 2007; Puolakanaho, Ahonen, Aro, Eklund, Leppänen, Poikkeus, Tolvanen, Torppa, \& Lyytinen, 2008).

The genesis of naming deficits has several explanations and researchers lack consensus concerning the basis of RND. Researchers claim that these difficulties may have several etiologies based on phonological or motor difficulties. Some authors support the viewpoint 
that RND appears to be the part of phonological processing difficulties and argue that naming deficits, particularly slow naming, are related to slowness of phonological processes (Wagner \& Torgesen, 1987). Other authors suggest RND as a general speed processing deficit of cognitive processes which involve both naming and phonological components (Wolf, 1991, 1999; Korhonen, 1995; Wolf \& Bowers, 1999; Messer \& Dockrell, 2006).

There are several possible explanations regarding how naming speed can be an impediment for many readers. Wolf (1999) and Wolf, O'Rourke, Gidney, Lovett, Cirino and Morris (2002) have offered two possible hypotheses to explain the effects of deficits in naming speed on reading difficulties, based on behavioral and neuropsychological evidence. One hypothesis claims that children with SRD perform visual processing of spatial components more slowly. According to the second hypothesis, the reduced naming speed refers to the dysfunction of general speed and timing problems which affect reading skills in many ways. Wolf (1999) suggests that the source of speed and timing problem is a central time-keeping mechanism. Naming speed can be defined as the central point of a speed and timing cascade which influences perception, lexical and motor processes. This general impairment of processing speed influences, in turn, both phonological and orthographical inputs. Readers with double deficits (naming speed and phonological difficulties) have identified constant reading difficulties (Wolf, 1999; Wolf et al., 2002).

Longitudinal studies have demonstrated that RND discovered at the pre-reading or early reading age (6-9 years) had not disappeared, and RN tasks were passed more slowly based on the number of mistakes by adolescence (Korhonen, 1995; Wolf 1999). The study of Korhonen (1995) is in line with other studies which have found that adults diagnosed with SRD differ from their naming speed from the control group.

Recent investigations have focused on the transparency of orthography of the language of children learning to read. The researchers have found out that transparency of orthography impacts on reading acquisition, predictors of reading progress. Children learning to read in transparent orthography tend to show less severe disorder, making fewer mistakes in the beginning phase of learning than children in deep orthography. RN is figured out to be an especially powerful predictor for SRD in consistent orthographies. RND tends to manifest at first in slow reading speed and after that in reading inaccuracy (Holopainen et al., 2001; Goswami, 2002; Aro, 2004; Seymour, Aro, \& Erskine, 2004; Guron \& Lundberg, 2004; Georgiou, Parrila, \& Papadopoulos, 2008; Serrano \& Defior, 2008).

Much research has been carried out to determine what the SRD predictors are in terms of RN skills and different orthographies. RN skills are investigated in Finnish (Lehtonen, 1993; Korhonen, 1995; Ahonen, Leppänen, \& Tuovinen, 2003; Aro, 2004; Heikkilä, 2005), Dutch (Van der Leij, Lyytinen, \& Zwarts, 2001), Spanish (Serrano \& Defior, 2008) and Portuguese (Albuquerque \& Simoes, 2010) and compared with the results in English (Wolf, 1999).

Although there is no consensus regarding some aspects of $\mathrm{RN}$, further theoretical investigations are needed. RN tests are considered reliable tools in practical assessment of SRD.

The aim of this longitudinal study - to investigate the developmental course of RN speed and the correlation between RN speed and reading. Two tests were conducted by the author: RN test and reading/decoding tests. RN test comprised six subtests: colours, num- 
bers, letters, objects, letters and numbers, colours, letters, numbers; reading/decoding test consisted tree subtests: words, sentences, non-words.

\section{Methodology}

\section{Sample}

The random sample consisted of 250 Estonian speaking children. Children's ages and testing periods ranged as follows: the first period of testing was from 6 years 0 months to 6 years 11 months (hereafter 6 years), the second period of testing - from 7 years 0 months to 7 years 11 months (hereafter 7 years) and the third period of testing - from 8 years 0 months to 8 years 11 months (hereafter 8 years).

All children attended regular kindergartens in the beginning of investigation. Diagnosed general cognitive, motor or speech and language difficulties were not observed. The data was collected from different cities and regions in Estonia.

\section{Experimental tasks and procedure}

Each child was required to complete six $\mathrm{RN}$ tasks and three reading tasks.

$R N$ test. The aim of the tasks was to assess a child's RN skills in terms of mistakes, self-correction of mistakes and time consumed for passing the subtest. Six subtests were utilized to assess RN skills of colours, numbers, letters, objects, letters and numbers, colours, letters and numbers. RN tasks were measured using "Nopean Sarjallisen Nimeämisen Testi" (Ahonen et al., 2003, adopted into Estonian by the author of this paper). The task was to name all randomly presented symbols on the A4 sheet and move quickly to the next item. In the case of mistakes, the child might have corrected him/herself. All performances were recorded on the individual score list. Some tasks were allowed for naming the colours, numbers, letters and objects sub-tests.

Reading/decoding test. The aim of the reading tasks was to assess the child's decoding skills in terms of time consumed for passing the subtests (in seconds). The experimental test battery consisted of three subtests compiled for this study.

1. Word reading/decoding subtest included 20 words matched to pictures.

2. Sentence reading/decoding subtest included 10 sentences matched to pictures.

3. Non-word reading/decoding subtest included ten non-words in basic phonological and syllabical structures commonly used in the Estonian language. Five nonwords decoding practice was allowed prior to the testing performance.

All reading/decoding performances recorded on the individual score list included the time consumed for passing the subtest.

The tests were administered to each child individually once per academic session from October to January. The testing process was approved using the standard process for children in kindergarten and schools by permission of parents. Testing sessions lasted approx- 
imately 30 minutes. Tasks were administered in the same order within the testing session for each participant.

Descriptive statistics, t-test and correlations were analysed statistically.

\section{Results}

The developmental course used for naming speed at the ages of 6, 7 and 8 is shown in Table 1 (Appendix). A t-test was applied to detect statistical significance in age differences in RN speed.

Naming speed decreased at the ages of 6,7 and 8. The most extensive growth (approximately $50 \%$ ) is notable in naming of the alphanumerical stimuli: N, L, NL, NLC.

The ranges of naming speed decreased within the explored period. Ranges and particularly maximum of naming speed of alphanumerical stimuli are decreased especially significantly.

The naming speed of all stimuli shows the tendency to decrease by age and growth of formal schooling as expected. The most rapid development is observed in decreasing naming speed and ranges of naming speed of alphanumerical stimuli between the ages of 6 and 7. These results affirm rapid growth in naming speed of alphanumerical stimuli and decrease of intra-group differences in the beginning of formal reading instruction.

Learning alphanumerical symbols and attaining the automaticity in reading process is considered to be in the main focus of the first periods of formal schooling. Progress in literacy study process is visible in decrease of rapid naming speed, especially in naming of alphanumerical stimuli. Colours and pictures as symbols are more familiar to children at the age of 6 already and therefore the development of naming speed of these stimuli is not so markable within an observed period.

These results, which are shown in Table 1 (Appendix), are consistent with the previous investigations highlighting the impact of formal schooling and starting to learn alphanumerical symbols in the context of growth of rapid naming speed (Wolf, 1986, 1999; Compton, 2003).

The correlation between rapid naming speed and decoding speed of words, sentences and non-words could be estimated as moderate and strong, correlation index $.24 \ldots .78$. Stronger links are visible between decoding speed and naming speed of alphanumeric (and mixed stimuli) than naming speed of non-alphanumeric stimuli. The strongest links appear between naming speed in age 6 and reading speed in age 8, from .27 (L) to .78 (NL). Naming speed at the age of 7 presents stronger links to decoding speed than naming speed at the age of 6 and 8. Different reading tasks exhibit similar correlation indexes. Any considerable differences are not visible within words, sentences and non-word reading tasks (Appendix, Tables 2 to 7 ). 


\section{Discussion and conclusions}

The results confirm two previously presented views about the developmental course of rapid naming and significant correlation between RN and reading/decoding performances in languages with high level of orthographic transparency.

The obtained results are congruent with previous studies in several aspects of RN skills already investigated: a performance improvement by age (Denckla \& Rudel 1974; Ahonen et al., 2003; Wolf \& Denckla, 2005), the greatest increase in rapid naming time is noticed in the beginning of formal reading instructions (Denckla \& Rudel 1974; Ahonen et al., 2003), the noticeably faster diminished alphanumerical (numbers, letters) stimulus naming (Ahonen et al., 2003).

Current findings are also in harmony with previous investigations and stress the results about the relationship between $\mathrm{RN}$ tasks and reading, especially in languages using regular or semi-regular orthographies. RN speed and reading speed is found to be moderately or strongly correlated in Dutch, Finnish, German, Italian, Spanish and Portugese studies (Wolf, 1986; Wagner \& Torgesen, 1987; Korhonen, 1995; Wolf \& Bowers, 1999; Holopainen et al., 2001; Aro, 2004; Seymour et al., 2004; Serrano \& Defior, 2008; Albuquerque \& Simones, 2010).

This investigation confirms the results according to Compton (2003), Lehtonen (1993), Savage and Fredricson (2005), Savage et al. (2007). The strongest association is between numbers naming speed and reading speed. According to findings by Denckla and Rudel (1974) and Wolf (1991), this research confirms mixed stimulus tests (RAS) naming speed to be more strongly associated with reading speed than simple stimulus (RN) tests. These findings support Albuquerque and Simoes (2010) conclusions to differentiate RN and RAS tests.

The current study was the first investigation in $\mathrm{RN}$ speed in highly regular Estonian language context. RN speed was investigated from the point of view of developmental course and correlation with reading speed. The research findings will guide how to use RN tests in early literacy assessment process in order to predict reading abilities and reading difficulties. The results obtained confirm that rapid naming skills are beneficial to investigate in order to predict reading/decoding skills, and rapid naming tests are relevant tools. Further statistical analyses are needed to elaborate what standards are age appropriate for rapid naming test used in this study.

\section{Acknowledgement:}

This work has been supported by the Estonian Doctoral School of Educational Sciences. Agreement No. 1.2.0401.09-0070. 


\section{References:}

Ahonen, T., Leppänen, T., \& Tuovinen, S. (2003). Nopean sarjallinen nimeämisen testi [Rapid serial naming test]. Jyväskylä: ER-Paino Oy, Lievestuore Publisher.

Albuquerque, C. P., \& Simoes, M. R. (2010). Rapid naming tests: Developmental course and relations with neuropsychological measures. The Spanish Journal of Psychology, 13(1), 88-100.

Arnell, K. M., Joanisse, M. F., Klein, R. M., Busseri, M. A., \& Tannock, R. (2009). Decomposing the relation between rapid automatized naming ( $\mathrm{ran}$ ) and reading ability. Canadian Journal of Experimental Psychology, 63(3), 173-184.

Aro, M. (2004). Learning to read. The effect of orthography. Jyväskylä: ER-Paino Ky, Lievestuore.

Boscardin, C. K., Muthén, B., David J. F., \& Baker, E. L. (2008). Early identification of reading difficulties using heterogeneous developmental trajectories. Journal of Educational Psychology, 100(1), 192-208. DOI: 10.1037/0022-0663.100.1.192.

Compton, D. L. (2003). Modeling the relationship between growth in rapid naming speed and growth in decoding skills in first-grade children. Journal of Educational Psychology, 95, 225-239.

Constable, A. (2001). A psycholinguistic approach to word-finding difficulties. In J. Stackhouse \& B. Wells (Eds.), Children's speech and literacy difficulties. Book 2: Identification and intervention (pp. 330-365). London: Wiley.

Denckla, M. B., \& Rudel, R. (1974). Rapid "automatized" naming of pictured objects, colors, letters and numbers by normal children. Cortex, 10, 186-202. DOI: 10.1016/00283932(76)90075-0.

Denckla, M. B., \& Rudel, R. (1976a). Rapid "automatized" naming (R.A.N.): Dyslexia differenciated from other learning disabilities. Neuropsychologia, 1976, 14, 471-179.

Denckla, M. B., \& Rudel, R. (1976b). Naming of objects-drawings by dyslexic and other learning disabled children. Brain and Language, 3, 1-15. DOI: 10.1016/0093934X(76 )90001-8.

Denckla, M. B., \& Cutting, L. E. (1999). History and significance of rapid automatized naming. Annals of Dyslexia, 49, 29-42. DOI: 10.1007/s11881-010-0043-8.

Estonian teachers' 5th professional standard. (2005). Retrieved April 20, 2010, from http://www.ht.ut.ee/580579

Georgiou, G. K., Parrila, R., \& Papadopoulos, T. C. (2008). Predictors of word decoding and reading fluency across languages varying in orthographic consistency. Journal of Educational Psychology, 100, 566-580. DOI: 10.1037/0022-0663.100.3.566.

German, D. J., \& Newman, R. S. (2007). Oral reading skills of children with oral language (word-finding) difficulties. Reading Psychology, 28, 397-442.

Geschwind, N. (1965). Disconnection syndrome in animals and man. Part I and II. Brain, 88, 237-294, 585-644.

Goswami, U. (2002). Phonology, reading development and dyslexia: A crosslinguisic perspective. Annals of Dyslexia, 52, 141-163.

Grigorenko, E. L. (2004). Genetic bases of developmental dyslexia: A capsule review of heritability estimates. Enfance, 3, 273-287. 
Guron, L. M., \& Lundberg, I. (2004). Error patterns in word reading among primary school children: A cross-orthographic study. Dyslexia, 10, 44-60.

Heikkilä, R. (2005). Nopea sarjallinen nimeäminen ja sen ühteydet kielellisiin ja eikielellisiin taitoihin - kirjallisuuskatsaus [Rapid serial naming, connection to language and pre-reading skill]. NMI bulletin: Oppimisvaikeuksien erityislehti [NMI bulletin: Learning difficulties] (pp. 15-35). Jyväskylä: Kirjapaino Oma Oy.

Heikkilä, R., Närhi, V., Aro, M., \& Ahonen, T. (2008). Rapid automatized naming and learning disabilities: Does RAN have a specific connection to reading or not? Children's Neuropsychology, 1, 1-16. DOI: 10.1080/09297040802537653.

Holopainen, L., Ahonen, T., \& Lyytinen, H. (2001). Predicting delay in reading achievement in a highly transparent language. Journal of Learning Disabilities, 34, 401-413.

Karlep, K. (2003). Kõnearendus. Emakeele abiõpe II [Speech development. Supportive teaching in mother tongue II]. Tartu: Tartu Ülikooli Kirjastus.

Korhonen, T. (1995). The persistence of rapid naming problems in children with reading disabilities: A nine-year follow-up. Journal of Learning Disabilities, 26, 232-239. DOI: $10.1177 / 002221949502800405$.

Kukk, A., \& Talts, L. (2007). Teachers' self-assessment of their professional skills according to the teachers' professional standard. Journal of Teacher Education for Sustainability, 8, 12-24.

Laine, M. (1995). Kuvan nimeäminen: kognitiivisen psykologian näkökulma [Naming of pictures from the perspective of cognitive psychology]. Psykologia, 30, 96-100.

Lehtonen, H. (1993). Lukutaidon kehittyminen ja sen yhteydet nimeämiseen, motivaation ja koulumenestykseen. Akateeminen väitoskirja [Development of reading skills and relations with naming, motivation and educational success]. Unpublished doctoral thesis, University of Tampere, Kalevantie, Finland.

Luria, A. R. (1962). Võsshije korkovõje funktsii tsheloveka [Higher cortical functions of man]. Moskva: Izdateljstvo Moskovskogo Universiteta.

Makarevičs, V. (2008). Professional competences of future teachers: Perspective of different evaluators and contexts. Journal of Teacher Education for Sustainability, 10, 6878.

Messer, D., \& Dockrell, J. E. (2006). Children's naming and word-finding difficulties: Descriptions and explanations. Journal of Speech, Language, and Hearing, 49, 309-324. DOI: 10.1044/1092-4388(2006/025).

Misra, M., Katzir, T., Wolf, M., \& Poldrack, R. A. (2004). Neural systems for rapid automatized naming in skilled readers: Unravelling the RAN-reading relationship. Scientific Studies of Reading, 8, 241-256. DOI: 10.1207/s1532799xssr0803_4.

Nation, K. (2005). Connections between language and reading in children with poor reading comprehension. In H. W. Catts \& A. G. Kamhi (Eds.), The connections between language and reading disabilities (pp. 37-66). Mahwah N. J.: London: Lawrence Erlbaum Associates.

National law of basic schools and gymnasiums. (2010). Retrieved May 14, 2011, from https://www.riigiteataja.ee/akt/13332410

Pandis, M. (2002). Lugemisoskus ja sellega seotud tegurid. Magistritöö [Reading skills and related factors]. Unpublished master's thesis, Tallinn University, Tallinn, Estonia. 
Pastarus, K. (1999). 5-6-aastaste laste lugemisoskuse eelduste uurimine [Reading predictions in 5-6 years old children]. In K. Karlep (Ed.), Töid eripedagoogikast XV [Papers in special education] (pp. 20-33). Tartu: Tartu Ülikooli Kirjastus.

Puolakanaho, A., Ahonen, T., Aro, M., Eklund, M., Leppänen, P. H. T., Poikkeus, A. M. Tolvanen, A., Torppa, M., \& Lyytinen, H. (2008). Developmental links of very early phonological and language skills to second grade reading outcomes: Strong to accuracy but only minor to fluency. Journal of Learning Disabilities, 41, 353-370. DOI: 10.1177/0022219407311747.

Salmi, P. (2008). Nimeäminen ja lukemisvaikeus. Kehityksen ja kuntoutuksen näkökulma. Akateeminen väitoskirja [Naming and reading difficulties. Development and treatment]. Unpublished doctoral thesis, University of Jyväskylä, Jyväskylä, Finland.

Samuelsson, S., Byrne, B., Quain, P., Wadsworth, S., Corley, R., DeFries, J. C., Willcutt, E., \& Olson, R. (2005). Environmental and genetic influences on prereading skills in Australia, Scandinavia, and the United States. Journal of Educational Psychology, 97(4), 705-722.

Savage, R., \& Fredricson, N. (2005). Evidence of a highly specific relationship between rapid automatic naming of digits and text-reading speed. Brain and Language, 93, 152-159. DOI: 10.1016/j.bandl.2004.09.005.

Savage, R., Pillay, V., \& Melidona, S. (2007). Deconstructing rapid automatized naming: Component processes and the prediction of reading difficulties. Learning and Individual Differencies, 17, 129-146. DOI: 10.1016/j.lindif.2007.04.001.

Scanavis, C., \& Sakellari, M. (2009). Education for sustainable development and hazard preparedness: A key to promote community engagement. 7th International JTEFS/BBCC Conference "Sustainable Development. Culture. Education.". Proceedings (Part 1, pp. 39-48). Daugavpils: Daugavpils University Academic Press "Saule".

Serrano, F., \& Defior, S. (2008). Dyslexia speed problems in a transparent orthography. Annals of Dyslexia, 58, 81-95. DOI: 10.1007/s11881-008-0013-6.

Seymour, P. H. K., Aro, M., \& Erskine, J. M. (2004). Foundation literacy acquisition in European orthographies. British Journal of Psychology, 94, 143-174. DOI: 10.1348/0 00712603321661859.

Shaywitz, S. (2003). Overcoming dyslexia. A new and complete science-based program for reading problems at any level. New York: Alfred A Knopf.

Stackhouse, J. (2006). Speech and spelling difficulties: What to look for. In M. J. Snowling \& J. Stackhouse (Eds.), Dyslexia, speech and language: A practitioner's handbook (pp. 15-35). London and Philadelphia: Whurr Publishers.

Van der Leij, A., Lyytinen, H., \& Zwarts, F. (2001). The study of infant cognitive processes in dyslexia. In A. J. Fawcett (Eds.), Dyslexia: Theory and good practice (pp. 160181). London: Whurr.

Waber, D. P., Wolff, P. H., Forbes, P. W., \& Weiler, M. D. (2000). Rapid automatized naming in children referred for evaluation of heterogeneous learning problems: How specific are naming speed deficits to reading disability? Child Neuropsychology, 6, 251-261. DOI: 10.1076/chin.6.4.251.3137.

Wagner, R. K., \& Torgesen, J. K. (1987). The nature of phonological processing and its casual role in the acquisition of reading skills. Psychological Bulletin, 101, 192-212. 
Wolf, M. (1986). Rapid alternating stimulus naming in the developmental dyslexias. Brain and Language, 27, 360-379.

Wolf, M. (1991). Naming speed and reading: The contribution of the cognitive neurosciences. Reading Research Quarterly, 26(2), 123-141.

Wolf, M. (1999). What time may tell: Towards a new conceptualization of developmental dyslexia. Annals of Dyslexia, 49, 3-28. DOI: 10.1007/s11881-999-0017-x.

Wolf, M., \& Bowers, P. (1999). The double-deficit hypothesis for the developmental dyslexia. Journal of Educational Psychology, 91, 1-24.

Wolf, M., \& Denckla, M. B. (2005). RAN/RAS. Rapid automatized and rapid alternating stimulus test. Examiner's manual. Austin, Texas: Pro-Ed.

Wolf, M., O’Rourke, A. G., Gidney, C., Lovett, M., Cirino, P., \& Morris, R. (2002). The second deficit: An investigation of phonological and naming-speed deficits in developmental dyslexia. Reading and Writing: An Interdiciplinary Journal, 15, 43-72.

Wolfe, P., \& Nevills, P. (2004). Building the reading brain, PreK-3. California: Corwin Press.

\section{Appendix}

Table 1. Naming speed in age $6-8, \mathrm{p}<0.01, \mathrm{n}=250$

\begin{tabular}{llllll}
\hline \multicolumn{7}{c}{ Descriptive Statistics } \\
\hline & Range & Minimum & Maximum & Mean & Std. Deviation \\
\hline C speed 6y & 122.99 & 33.52 & 156.51 & 70.20595745 & 19.1762445 \\
\hline C speed 7y & 105.13 & 31.71 & 136.84 & 58.91602837 & 17.60842739 \\
\hline C speed 8y & 66.18 & 32.52 & 98.7 & 50.85117021 & 10.56675831 \\
\hline N speed 6y & 264.02 & 25.15 & 289.17 & 63.6837218 & 33.35412248 \\
\hline N speed 7y & 100.88 & 19.89 & 120.77 & 41.06276596 & 12.58229064 \\
\hline N speed 8y & 69.22 & 19.12 & 88.34 & 32.50212766 & 8.016791524 \\
\hline L speed 6y & 135.22 & 20.25 & 155.47 & 53.00776119 & 20.61607971 \\
\hline L speed 7y & 80.15 & 21.01 & 101.16 & 38.14826241 & 11.02256415 \\
\hline L speed 8y & 39.74 & 19.98 & 59.72 & 32.53897163 & 7.188478227 \\
\hline P speed 6y & 107.01 & 42.03 & 149.04 & 71.1344484 & 16.9880911 \\
\hline P speed 7y & 102.07 & 32.07 & 134.14 & 59.94911702 & 15.82304575 \\
\hline P speed 8y & 57.22 & 25.47 & 82.69 & 50.74124113 & 8.941097536 \\
\hline NL speed 6y & 204.41 & 34.04 & 238.45 & 72.34113725 & 28.45221387 \\
\hline NL speed 7y & 107.59 & 26.82 & 134.41 & 48.81503652 & 15.29825347 \\
\hline NL speed 8y & 63.81 & 23.35 & 87.16 & 38.43847518 & 8.196798013 \\
\hline NLC speed 6y & 152.24 & 39.55 & 191.79 & 78.38287402 & 28.73974905 \\
\hline NLC speed 7y & 94.86 & 29.02 & 123.88 & 55.94553191 & 17.25396071 \\
\hline NLCspeed 8y & 61.25 & 19.66 & 80.91 & 43.88294326 & 9.341858704 \\
\hline Valid N 250 & & & & & \\
\hline
\end{tabular}


Table 2. Relationship between naming speed of colours (C) and decoding speed

\begin{tabular}{|c|c|c|c|c|c|c|c|c|c|}
\hline & & $\begin{array}{l}\text { words } \text { sent-s } \\
\text { speed } 7 \text { y speed } 7 y\end{array}$ & $\begin{array}{l}\text { non- } \\
\text { words } \\
\text { speed } 7 y\end{array}$ & $\begin{array}{l}\text { words } \\
\text { speed } 8 y\end{array}$ & $\begin{array}{l}\text { sent-s } \\
\text { speed } 8 y\end{array}$ & $\begin{array}{l}\text { non- } \\
\text { words } \\
\text { speed } 8 y\end{array}$ & $\begin{array}{l}\text { C speed } \\
6 y\end{array}$ & $\begin{array}{l}\text { C speed } \\
7 y\end{array}$ & $\begin{array}{l}\text { C speed } \\
8 y\end{array}$ \\
\hline $\begin{array}{l}\text { words } \\
\text { speed } 7 y\end{array}$ & $\begin{array}{l}\text { Pearson } \\
\text { correlation }\end{array}$ & & & & & & & & \\
\hline $\begin{array}{l}\text { sent-s } \\
\text { speed } 7 y\end{array}$ & $\begin{array}{l}\text { Pearson } \\
\text { correlation } \\
\end{array}$ & $.873(* *) 1$ & & & & & & & \\
\hline $\begin{array}{l}\text { non- } \\
\text { words } \\
\text { speed } 7 y\end{array}$ & $\begin{array}{l}\text { Pearson } \\
\text { correlation }\end{array}$ & $.770(* *) .773(* *)$ & 1 & & & & & & \\
\hline $\begin{array}{l}\text { words } \\
\text { speed } 8 y\end{array}$ & $\begin{array}{l}\text { Pearson } \\
\text { correlation }\end{array}$ & $.528(* *) .533(* *)$ & $.539(* *)$ & 1 & & & & & \\
\hline $\begin{array}{l}\text { sent-s } \\
\text { speed } 8 y\end{array}$ & $\begin{array}{l}\text { Pearson } \\
\text { correlation }\end{array}$ & $.500(* *) .513(* *)$ & $.522(* *)$ & $.721(* *)$ & 1 & & & & \\
\hline $\begin{array}{l}\text { non- } \\
\text { words } \\
\text { speed } 8 y\end{array}$ & $\begin{array}{l}\text { Pearson } \\
\text { correlation }\end{array}$ & $.389(* *) .384(* *)$ & $.440(* *)$ & $.643(* *)$ & $.633(* *)$ & 1 & & & \\
\hline $\begin{array}{l}\text { C speed } \\
6 \mathrm{y}\end{array}$ & $\begin{array}{l}\text { Pearson } \\
\text { correlation }\end{array}$ & $.353(* *) .346(* *)$ & $.373(* *)$ & $.363(* *)$ & $.284(* *)$ & $.245(* *)$ & 1 & & \\
\hline $\begin{array}{l}\text { C speed } \\
7 y\end{array}$ & $\begin{array}{l}\text { Pearson } \\
\text { correlation }\end{array}$ & $.566(* *) .585(* *)$ & $.475(* *)$ & $.400(* *)$ & $.296(* *)$ & $.296(* *)$ & $.530(* *)$ & 1 & \\
\hline $\begin{array}{l}\text { c speed } \\
8 \mathrm{y}\end{array}$ & $\begin{array}{l}\text { Pearson } \\
\text { correlation }\end{array}$ & $.327(* *) .331(* *)$ & $.315(* *)$ & $.363(* *)$ & $.274(* *)$ & $.255(* *)$ & $.573(* *)$ & $.596(* *)$ & 1 \\
\hline
\end{tabular}

Table 3. Relationship between naming speed of numbers $(\mathrm{N})$ and decoding speed

\begin{tabular}{|c|c|c|c|c|c|c|c|c|c|c|}
\hline & & $\begin{array}{l}\text { words } \\
\text { speed } 7 y\end{array}$ & $\begin{array}{l}\text { sent-s } \\
\text { speed } 7 y\end{array}$ & $\begin{array}{l}\text { non- } \\
\text { words } \\
\text { speed } 7 y\end{array}$ & $\begin{array}{l}\text { words } \\
\text { speed } 8 y\end{array}$ & $\begin{array}{l}\text { sent-s } \\
\text { speed } 8 y\end{array}$ & $\begin{array}{l}\text { non- } \\
\text { words } \\
\text { speed } 8 y\end{array}$ & $\begin{array}{l}\text { N speed } \\
6 y\end{array}$ & $\begin{array}{l}\text { N speed } \\
7 y\end{array}$ & $\begin{array}{l}\text { N speed } \\
8 y\end{array}$ \\
\hline $\begin{array}{l}\text { words } \\
\text { speed } 7 y\end{array}$ & $\begin{array}{l}\text { Pearson } \\
\text { correlation }\end{array}$ & 1 & & & & & & & & \\
\hline $\begin{array}{l}\text { sent-s } \\
\text { speed 7y }\end{array}$ & $\begin{array}{l}\text { Pearson } \\
\text { correlation }\end{array}$ & $.873(* *)$ & 1 & & & & & & & \\
\hline $\begin{array}{l}\text { non- } \\
\text { words } \\
\text { speed } 7 y\end{array}$ & $\begin{array}{l}\text { Pearson } \\
\text { correlation }\end{array}$ & $.770(* *)$ & $.773(* *)$ & 1 & & & & & & \\
\hline $\begin{array}{l}\text { words } \\
\text { speed } 8 \mathrm{y}\end{array}$ & $\begin{array}{l}\text { Pearson } \\
\text { correlation }\end{array}$ & $.528(* *)$ & $.533(* *)$ & $.539(* *)$ & 1 & & & & & \\
\hline $\begin{array}{l}\text { sent-s } \\
\text { speed 8y }\end{array}$ & $\begin{array}{l}\text { Pearson } \\
\text { correlation }\end{array}$ & $.500(* *)$ & $.513(* *)$ & $.522(* *)$ & $.721(* *)$ & 1 & & & & \\
\hline $\begin{array}{l}\text { non- } \\
\text { words } \\
\text { speed } 8 y \\
\end{array}$ & $\begin{array}{l}\text { Pearson } \\
\text { correlation }\end{array}$ & $.389(* *)$ & $.384(* *)$ & $.440(* *)$ & $.643(* *)$ & $.633(* *)$ & 1 & & & \\
\hline $\begin{array}{l}\text { N speed } \\
6 y\end{array}$ & $\begin{array}{l}\text { Pearson } \\
\text { correlation }\end{array}$ & $.414(* *)$ & $.429(* *)$ & $.410(* *)$ & $.446(* *)$ & $.424(* *)$ & $.392(* *)$ & 1 & & \\
\hline $\begin{array}{l}\mathrm{N} \text { speed } \\
7 \mathrm{y}\end{array}$ & $\begin{array}{l}\text { Pearson } \\
\text { correlation }\end{array}$ & $.682(* *)$ & $.692(* *)$ & $.648(* *)$ & $.422(* *)$ & $.452(* *)$ & $.317(* *)$ & $.521(* *)$ & 1 & \\
\hline $\begin{array}{l}\mathrm{N} \text { speed } \\
8 \mathrm{y}\end{array}$ & $\begin{array}{l}\text { Pearson } \\
\text { correlation }\end{array}$ & $.284(* *)$ & $.293(* *)$ & $.305(* *)$ & $.389(* *)$ & $.363(* *)$ & $.364(* *)$ & $.352(* *)$ & $.446(* *)$ & 1 \\
\hline
\end{tabular}


Table 4. Relationship between naming speed of letters (L) and decoding speed

\begin{tabular}{|c|c|c|c|c|c|c|c|c|}
\hline & & $\begin{array}{l}\text { words } \text { sent-s } \\
\text { speed } 7 \text { yspeed } 7 y\end{array}$ & $\begin{array}{l}\text { non- } \\
\text { words } \\
\text { speed } 7 y\end{array}$ & $\begin{array}{l}\text { words } \\
\text { speed } 8 y\end{array}$ & $\begin{array}{l}\text { sent-s } \\
\text { speed 8y }\end{array}$ & $\begin{array}{l}\text { non- } \\
\text { words } \\
\text { speed } 8 y\end{array}$ & $\begin{array}{l}\text { L speed } \\
6 y\end{array}$ & L speed $7 y \begin{array}{l}\text { L speed } \\
8 y\end{array}$ \\
\hline $\begin{array}{l}\text { words } \\
\text { speed } 7 \mathrm{y}\end{array}$ & $\begin{array}{l}\text { Pearson } \\
\text { correlation }\end{array}$ & 1 & & & & & & \\
\hline $\begin{array}{l}\text { sent-s } \\
\text { speed } 7 y\end{array}$ & $\begin{array}{l}\text { Pearson } \\
\text { correlation }\end{array}$ & $.873(* *) 1$ & & & & & & \\
\hline $\begin{array}{l}\text { non- } \\
\text { words } \\
\text { speed } 7 y\end{array}$ & $\begin{array}{l}\text { Pearson } \\
\text { correlation }\end{array}$ & $.770(* *) .773(* *)$ & 1 & & & & & \\
\hline $\begin{array}{l}\text { words } \\
\text { speed } 8 \mathrm{y}\end{array}$ & $\begin{array}{l}\text { Pearson } \\
\text { correlation }\end{array}$ & $.528(* *) .533(* *)$ & $.539(* *)$ & 1 & & & & \\
\hline $\begin{array}{l}\text { sent-s } \\
\text { speed } 8 y\end{array}$ & $\begin{array}{l}\text { Pearson } \\
\text { correlation }\end{array}$ & $.500(* *) .513(* *)$ & $.522(* *)$ & $.721(* *)$ & 1 & & & \\
\hline $\begin{array}{l}\text { non- } \\
\text { words } \\
\text { speed } 8 y\end{array}$ & $\begin{array}{l}\text { Pearson } \\
\text { correlation }\end{array}$ & $.389(* *) .384(* *)$ & $.440(* *)$ & $.643(* *)$ & $.633(* *)$ & 1 & & \\
\hline $\begin{array}{l}\text { L speed } \\
6 y\end{array}$ & $\begin{array}{l}\text { Pearson } \\
\text { correlation }\end{array}$ & $.392(* *) .416(* *)$ & $.387(* *)$ & $.426(* *)$ & $.336(* *)$ & $.381(* *)$ & 1 & \\
\hline $\begin{array}{l}\text { L speed } \\
7 \mathrm{y}\end{array}$ & $\begin{array}{l}\text { Pearson } \\
\text { correlation }\end{array}$ & $.504(* *) .530(* *)$ & $.553(* *)$ & $.475(* *)$ & $.413(* *)$ & $.406(* *)$ & $.363(* *)$ & 1 \\
\hline $\begin{array}{l}\text { L speed } \\
8 y\end{array}$ & $\begin{array}{l}\text { Pearson } \\
\text { correlation }\end{array}$ & $.240(* *) .207(* *)$ & $.268(* *)$ & $.356(* *)$ & $.292(* *)$ & $.376(* *)$ & $.205(* *)$ & $.372(* *)$ \\
\hline
\end{tabular}

Table 5. Relationship between naming speed of picture (P) and decoding speed

\begin{tabular}{|c|c|c|c|c|c|c|c|c|c|}
\hline & & $\begin{array}{l}\text { words sent-s } \\
\text { speed } 7 \text { yspeed } 7 y\end{array}$ & $\begin{array}{l}\text { non- } \\
\text { words } \\
\text { speed } 7 y\end{array}$ & $\begin{array}{l}\text { words } \\
\text { speed } 8 y\end{array}$ & $\begin{array}{l}\text { sent-s } \\
\text { speed } 8 y\end{array}$ & $\begin{array}{l}\text { non- } \\
\text { words } \\
\text { speed } 8 y\end{array}$ & $\begin{array}{l}\text { P speed } \\
6 y\end{array}$ & $\begin{array}{l}\text { P speed } \\
7 y\end{array}$ & $\begin{array}{l}\text { P speed } \\
8 y\end{array}$ \\
\hline $\begin{array}{l}\text { words } \\
\text { speed } 7 \mathrm{y}\end{array}$ & $\begin{array}{l}\text { Pearson } \\
\text { correlation }\end{array}$ & 1 & & & & & & & \\
\hline $\begin{array}{l}\text { sent-s } \\
\text { speed 7y }\end{array}$ & $\begin{array}{l}\text { Pearson } \\
\text { correlation }\end{array}$ & $.873(* *) 1$ & & & & & & & \\
\hline $\begin{array}{l}\text { non- } \\
\text { words } \\
\text { speed } 7 y\end{array}$ & $\begin{array}{l}\text { Pearson } \\
\text { correlation }\end{array}$ & $.770(* *) .773(* *)$ & 1 & & & & & & \\
\hline $\begin{array}{l}\text { words } \\
\text { speed } 8 \mathrm{y}\end{array}$ & $\begin{array}{l}\text { Pearson } \\
\text { correlation }\end{array}$ & $.528(* *) .533(* *)$ & $.539(* *)$ & 1 & & & & & \\
\hline $\begin{array}{l}\text { sent-s } \\
\text { speed } 8 y\end{array}$ & $\begin{array}{l}\text { Pearson } \\
\text { correlation }\end{array}$ & $.500(* *) .513(* *)$ & $.522(* *)$ & $.721(* *)$ & 1 & & & & \\
\hline $\begin{array}{l}\text { non- } \\
\text { words } \\
\text { speed } 8 y\end{array}$ & $\begin{array}{l}\text { Pearson } \\
\text { correlation }\end{array}$ & $.389(* *) .384(* *)$ & $.440(* *)$ & $.643(* *)$ & $.633(* *)$ & 1 & & & \\
\hline $\begin{array}{l}\text { P speed } \\
6 y\end{array}$ & $\begin{array}{l}\text { Pearson } \\
\text { correlation }\end{array}$ & $.322(* *) .303(* *)$ & $.336(* *)$ & $.384(* *)$ & $.366(* *)$ & $.265(* *)$ & 1 & & \\
\hline $\begin{array}{l}\text { P speed } \\
7 \mathrm{y}\end{array}$ & $\begin{array}{l}\text { Pearson } \\
\text { correlation }\end{array}$ & $.553(* *) .570(* *)$ & $.445(* *)$ & $.338(* *)$ & $.260(* *)$ & $.261(* *)$ & $.455(* *)$ & 1 & \\
\hline $\begin{array}{l}\mathrm{P} \text { speed } \\
8 \mathrm{y}\end{array}$ & $\begin{array}{l}\text { Pearson } \\
\text { correlation }\end{array}$ & $.351(* *) .353(* *)$ & $.357(* *)$ & $.451(* *)$ & $.421(* *)$ & $.345(* *)$ & $.547(* *)$ & $.513(* *)$ & 1 \\
\hline
\end{tabular}


Table 6. Relationship between naming speed of numbers and letters (NL) and decoding speed

\begin{tabular}{|c|c|c|c|c|c|c|c|}
\hline & & $\begin{array}{l}\text { words } \quad \text { sent-s } \\
\text { speed } 7 \text { yspeed } 7 y\end{array}$ & $\begin{array}{l}\text { non- } \\
\text { words } \\
\text { speed } 7 y\end{array}$ & $\begin{array}{l}\text { words } \\
\text { speed } 8 y\end{array}$ & $\begin{array}{l}\text { sent-s } \\
\text { speed } 8 y\end{array}$ & $\begin{array}{l}\text { non- } \\
\text { words } \\
\text { speed } 8 y\end{array}$ & $\begin{array}{l}\text { NL } \text { speed NL } \text { speed NL speed } \\
6 y \quad 7 y \quad 8 y\end{array}$ \\
\hline $\begin{array}{l}\text { words } \\
\text { speed } 7 y\end{array}$ & $\begin{array}{l}\text { Pearson } \\
\text { correlation }\end{array}$ & & & & & & \\
\hline $\begin{array}{l}\text { sent-s } \\
\text { speed } 7 y\end{array}$ & $\begin{array}{l}\text { Pearson } \\
\text { correlation }\end{array}$ & $.873(* *) 1$ & & & & & \\
\hline $\begin{array}{l}\text { non- } \\
\text { words } \\
\text { speed } 7 y\end{array}$ & $\begin{array}{l}\text { Pearson } \\
\text { correlation }\end{array}$ & $.770(* *) .773(* *)$ & 1 & & & & \\
\hline $\begin{array}{l}\text { words } \\
\text { speed } 8 \mathrm{y}\end{array}$ & $\begin{array}{l}\text { Pearson } \\
\text { correlation }\end{array}$ & $.528(* *) .533(* *)$ & $.539(* *)$ & 1 & & & \\
\hline $\begin{array}{l}\text { sent-s } \\
\text { speed } 8 y\end{array}$ & $\begin{array}{l}\text { Pearson } \\
\text { correlation }\end{array}$ & $.500(* *) .513(* *)$ & $.522(* *)$ & $.721(* *)$ & 1 & & \\
\hline $\begin{array}{l}\text { non- } \\
\text { words } \\
\text { speed } 8 y\end{array}$ & $\begin{array}{l}\text { Pearson } \\
\text { correlation }\end{array}$ & $.389(* *) .384(* *)$ & $.440(* *)$ & $.643(* *)$ & $.633(* *)$ & 1 & \\
\hline $\begin{array}{l}\text { NL speed } \\
6 y\end{array}$ & $\begin{array}{l}\text { Pearson } \\
\text { correlation }\end{array}$ & $.423(* *) .422(* *)$ & $.400(* *)$ & $.467(* *)$ & $.473(* *)$ & $.438(* *)$ & 1 \\
\hline $\begin{array}{l}\text { NL speed } \\
7 \mathrm{y}\end{array}$ & $\begin{array}{l}\text { Pearson } \\
\text { correlation }\end{array}$ & $.756(* *) .787(* *)$ & $.703(* *)$ & $.495(* *)$ & $.476(* *)$ & $.449(* *)$ & $.490(* *) \quad 1$ \\
\hline $\begin{array}{l}\text { NL speed } \\
8 \mathrm{y}\end{array}$ & $\begin{array}{l}\text { Pearson } \\
\text { correlation }\end{array}$ & $.475(* *) .525(* *)$ & $.452(* *)$ & $.532(* *)$ & $.562(* *)$ & $.489(* *)$ & $.469(* *) \quad .534(* *) \quad 1$ \\
\hline
\end{tabular}

Table 7. Relationship between naming speed of numbers, letters and colours (NLC) and growth in decoding speed

\begin{tabular}{|c|c|c|c|c|c|c|c|c|c|}
\hline & & $\begin{array}{l}\text { words } \text { sent-s } \\
\text { speed } 7 y \text { speed } 7 y\end{array}$ & $\begin{array}{l}\text { non- } \\
\text { words } \\
\text { speed } 7 y\end{array}$ & $\begin{array}{l}\text { words } \\
\text { speed } 8 y\end{array}$ & $\begin{array}{l}\text { sent-s } \\
\text { speed } 8 y\end{array}$ & $\begin{array}{l}\text { non- } \\
\text { words } \\
\text { speed } 8 y\end{array}$ & $\begin{array}{l}\text { NLC } \\
\text { speed 6y }\end{array}$ & $\begin{array}{l}\text { NLC } \\
\text { speed 7y }\end{array}$ & $\begin{array}{l}\text { NLC } \\
\text { speed 8y }\end{array}$ \\
\hline $\begin{array}{l}\text { words } \\
\text { speed } 7 \mathrm{y}\end{array}$ & $\begin{array}{l}\text { Pearson } \\
\text { correlation }\end{array}$ & & & & & & & & \\
\hline $\begin{array}{l}\text { sent-s } \\
\text { speed } 7 y\end{array}$ & $\begin{array}{l}\text { Pearson } \\
\text { correlation }\end{array}$ & $.873(* *) 1$ & & & & & & & \\
\hline $\begin{array}{l}\text { non- } \\
\text { words } \\
\text { speed } 7 y\end{array}$ & $\begin{array}{l}\text { Pearson } \\
\text { correlation }\end{array}$ & $.770(* *) .773(* *)$ & 1 & & & & & & \\
\hline $\begin{array}{l}\text { words } \\
\text { speed } 8 \mathrm{y}\end{array}$ & $\begin{array}{l}\text { Pearson } \\
\text { correlation }\end{array}$ & $.528(* *) .533(* *)$ & $.539(* *)$ & 1 & & & & & \\
\hline $\begin{array}{l}\text { sent-s } \\
\text { speed } 8 y\end{array}$ & $\begin{array}{l}\text { Pearson } \\
\text { correlation }\end{array}$ & $.500(* *) .513(* *)$ & $.522(* *)$ & $.721(* *)$ & 1 & & & & \\
\hline $\begin{array}{l}\text { non- } \\
\text { words } \\
\text { speed } 8 y\end{array}$ & $\begin{array}{l}\text { Pearson } \\
\text { correlation }\end{array}$ & $.389(* *) .384(* *)$ & $.440(* *)$ & $.643(* *)$ & $.633(* *)$ & 1 & & & \\
\hline $\begin{array}{l}\text { NLC } \\
\text { speed 6y }\end{array}$ & $\begin{array}{l}\text { Pearson } \\
\text { correlation }\end{array}$ & $.402(* *) .429(* *)$ & $.430(* *)$ & $.481(* *)$ & $.471(* *)$ & $.429(* *)$ & 1 & & \\
\hline $\begin{array}{l}\text { NLC } \\
\text { speed 7y }\end{array}$ & $\begin{array}{l}\text { Pearson } \\
\text { correlation }\end{array}$ & $.598(* *) .638(* *)$ & $.557(* *)$ & $.504(* *)$ & $.442(* *)$ & $.467(* *)$ & $.514(* *)$ & 1 & \\
\hline $\begin{array}{l}\text { NLC } \\
\text { speed 8y }\end{array}$ & $\begin{array}{l}\text { Pearson } \\
\text { correlation }\end{array}$ & $.416(* *) .436(* *)$ & $.391(* *)$ & $.484(* *)$ & $.508(* *)$ & $.460(* *)$ & $.495(* *)$ & $.514(* *)$ & 1 \\
\hline
\end{tabular}




\section{Correspondence:}

Kadi Lukanenok, MA, Institute of Educational Sciences, Tallinn University, Narva Road 25, Tallinn, 12120, Estonia. Email: kadi.lukanenok@tlu.ee 